\title{
School Textbooks with Updated Content in Kazakhstan in the Aspect of Education Reform
}

\author{
Eleonora D. Suleimenova ${ }^{a}$, \\ Gulmira E. Kozhamkulovab \\ and Kuralay B. Urazaeva ${ }^{\text {c* }}$ \\ a Al-Farabi Kazakh National University \\ 71 Al-Farabi, Almaty, 050040, Kazakhstan \\ ${ }^{b}$ Nazarbayev Intellectual Schools \\ 35/31 Street Str., Astana, 010000, Kazakhstan \\ ${ }^{c}$ Eurasian National University \\ 2 Satpayev Str., Astana, 010008, Kazakhstan
}

Implementation of the reform in the system of school education in the Republic of Kazakhstan, which was caused by the need to create competitive education against the background of increased educational migration (the outflow of school leavers) and the importance of developing a policy of "reverse" migration, led to the development of new standards, program models and textbooks with updated content. The transition to trilingualism, particularly, the teaching of biology, chemistry and informatics in the $10^{\text {th }}-11^{\text {th }}$ grades in English from 2019, is a part of the introduction of the model tested in Nazarbaev Intellectual Schools that demonstrated high results in PISA in the general education school.

The article describes the factors of the reform in education and the experience of developing an educational and methodological complex on the subject "Russian Language and Literature" for the 6th grade of non-Russian language general education school. Modern understanding of teaching effectiveness and advantages of a communicative-activity approach is illustrated by examples of a new goal-setting, differentiation and progression, organization and combination of types of learning activity, a new approach to evaluation as an element of teaching, and the application of an intersubject approach. The methodological basis of the article is characterized by the application of modern concepts relating to advances in didactics, rhetoric and linguoculturology.

The results obtained by the authors can be used in the field of didactics of the secondary and higher schools in terms of active teaching methods, comprehensive training of speech activity and methods of teaching the speech disciplines to the national audience.

The authors describe the experience in developing the skills of free speaking, argumentative writing, interpretation of a "foreign" text, and also substantiate the practical significance of the above mentioned skills for the successful social integration of students.

Keywords: russian language and literature, Kazakhstan, secondary school, education reform, communicative-activity approach, updated content.

DOI: 10.17516/1997-1370-0288.

Research area: pedagogy.

(C) Siberian Federal University. All rights reserved

* Corresponding author E-mail address: esuleim@gmail.com; kozhamkulova_g@cep.nis.edu.kz; kuralay_uraz@mail.ru 


\section{Introduction to the research problem}

The system of school education has brought into focus the most acute debating issues recently, since the most principal social problems are most consistently identified here. For Kazakhstan, the interrelation of social and educational problems was marked by the migration of school leavers from Kazakhstan, mainly from the border regions, to higher educational institutions of Russia. As the head of the Association of Higher Educational Institutions of Kazakhstan, Professor Rakhman Alshanov noted, a special surge in the outflow of graduates abroad was recorded in 2016: out of 121 thousand graduates more than 70 thousand preferred Russian universities. As the scientist observes, "Russia has become more active. They (representatives of Russian universities - E.S., G.K., K.U.) come to Kazakhstan universities, offer ... scholarships for admission, a hostel and job placement. Simultaneously, they simplified the rules of admission. This year, 136269 graduates left the schools. It turns out, approximately 15-20 thousand can go to foreign universities. Surely 70 percent of them can enter Russian universities," the expert predicts (Igisinova, 2017, Online). For several years Kazakhstan has been the leader among the rest of Central Asian countries in terms of the number of students studying at Russian universities. In 2015-2016 school year, there were 73455 students in Russia who came from Kazakhstan.

When asked about how to stop the brain drain, the Kazakh political expert Dosym Satpaev cites the policy of "reverse migration" as a measure of encouragement for "a return of the already prepared specialists to their habitual environment of brain competition" (Satpaev, 2017). The expert gives an example of China, where the basis for a technological breakthrough is related to the work of the Chinese state ideological machine to form the image of a new country. According to the expert, the solution of the problem of reverse migration is connected with the creation of an innovative knowledge economy as a real embodiment of the state program of "modernization of consciousness" as the main ideological direction for the state.

Developing the idea of one of the articles devoted to the generation of segregation in education by social ceilings, D. Satpaev highlights a real improvement of people's living standards, a rigid internal competition of knowledge, an equal access to quality education, which is ensured not by a diploma, but by the skills of continuous learning throughout life among the four conditions for the realization of the "knowledge economy" as a sign of a competitive state. At the same time, the researcher pays attention to an equal access to quality education in all regions of Kazakhstan, and not only in the capital or Almaty, which contributes to the solution of another problem that is "equalizing the social and economic disparities between different regions of the country by increasing their competitiveness" (Satpaev, 2017).

It is not by chance that public discussions provoked by criticism of Russian language textbooks for the $5^{\text {th }}$ and $7^{\text {th }}$ grades of the Mektep publishing house, as well as for the $5^{\text {th }}$ grades published by Nazarbaev Intellectual Schools (NIS) (Zagribel'nyi, 2017a, 2017b), textbooks for schools with a non-Russian language of study, written in the technology of a communicativeactivity approach, were held in the cities bordering Russia, namely, Uralsk, Ust-Kamenogorsk, Kokshetau (former Kokchetav), which is close to the northern borders of Kazakhstan. Concerns about discrepancies in the standards of school education in neighboring countries and, as a consequence, the lack of readiness for entrance examinations in Russia of Kazakh school leavers, have aroused skepticism in society about the 
justification of the reform in education at this time (Boranbaeva, 2017a, 2017b).

The high activity of parents and the public through the media led to public hearings in the border regions with the participation of teachers, local departments of education, representatives of the Ministry of Education and Science of the Republic of Kazakhstan, the National Academy of Education named after Y. Altynsarin, the Center for Educational Programs (CEP) of NIS. Fears of the public about the threat of mass illiteracy, the rejection of new approaches to teaching the Russian language, even the theories of conspiracy against the peoples of Kazakhstan and the future began to grow into demands for a moratorium on the implementation of the education reform, on the unpreparedness of schools to transfer the model tested in NIS, despite the good results on the basis of PISA (Program for international student assessment) (Kazakhstan zanial 59 mesto, 2017).

Discussions led to the hearings in the country's parliament, and from November 13 to November 28, 2017, 16 regions of the country held the meetings of the authors of textbooks with the updated content of all publishers for the $3^{\text {rd }}, 6^{\text {th }}$ and $8^{\text {th }}$ grades with the country's teachers. These events are called a practical evaluation of textbooks. The discussion of textbooks on the website of the Republican Scientific and Practical Center "Textbook" of the Ministry of Education and Science of the Republic of Kazakhstan from October 1 this year has the form of a public examination (Sait Respublikanskogo nauchnoprakticheskogo..., 2017). These two stages of the examination, in addition to the evaluation of experts, are designed to provide an objective and professional level of quality control of educational literature and the effectiveness of the educational reform.

The review of the results of PISA-2009 and PISA-2011 studies showed the following. In
2012, 15-year-old students of Kazakhstan showed the highest result of an average score increase among 65 countries in terms of mathematical and natural science competence. The analysis of reading literacy revealed a slight increase in the average result: by 3 points (from 390 to 393 points). In 2012, according to the level of literacy, students from Kazakhstan took the $60^{\text {th }}$ place, in 2009 they took the $59^{\text {th }}$ place. Reading literacy showed a difference of 37 points; it turned out that girls are more addicted to reading than boys. The analysis of the results shows that the students of urban schools demonstrate better results than rural ones.

In the field of reading literacy, participants were required to understand the content of a text that presented conflicting complex information, interpret a text in detail and accurately, critically evaluate a complex text on an unfamiliar topic, comprehend a text, relying on academic knowledge. $57.1 \%$ of Kazakhstan schoolchildren did not reach the threshold level of literacy. This means that they are not ready to navigate using texts, even in simple, familiar everyday situations. According to the levels of reading literacy, the proportion of students from Kazakhstan who are ready to use more or less complex texts for orientation in everyday situations relatively in an adequate way (level 2 and higher) was $42.9 \%$. A comparative analysis of the results showed a gap with the leading countries in the PISA study in all directions on average by 100 points. These results make it possible to judge that two-thirds of students in the leading countries have a level of functional literacy exceeding the average level of literacy of Kazakhstani students.

It was revealed that 15-year-old Kazakhstan students are most successful in coping with the tasks of the first, second and third levels of complexity, i.e. they are able to apply certain knowledge in simple situations. Difficulties are caused by the fulfillment of the tasks of the fifth 
and sixth levels of complexity, which means unavailability to comprehend and solve the problematic situation, to reason logically and critically and substantiate conclusions.

A serious concern was caused by the lack of progress in reading literacy. Meanwhile, reading literacy is the basic functional literacy that develops the ability to logically, reasonably and clearly build oral and written speech, as well as the ability to perceive, generalize and analyze information.

It is known that the term "functional literacy" first appeared in the late sixties of the last century in UNESCO documents and later came into use by researchers. The Organization for Economic Cooperation and Development (OECD) defines functional literacy as the ability of learners to apply their knowledge in real life, effectively analyze, substantiate, communicate and solve problems in various situations. In other words, the ability to apply learning in real life situations is a key component of functional literacy, making it the basis of competency and competitiveness of the individual, regardless of the level or profile of the training (Progress funktsional'noi gramotnosti..., 2014: 10-11).

The education reform is regulated by the National Action Plan for the Development of Functional Literacy, which involves the introduction of new methods for the individual development of children's abilities, the development of motivational mechanisms that cause children's interest in the learning process. The monitoring and analysis of the development of functional literacy and studying international experience of reforms with the purpose of adapting the best practices to the school system of Kazakhstan caused the development of new standard programs and textbooks with updated content.

The main direction of the reform is the revision of the goal-setting, in which the displacement of studying is carried out from narrow-subject skills to meta-subject skills of students. In modern science, in connection with the concept of 4-dimensional education, which includes four facets that are knowledge, skills, personal qualities and meta-training, the central place belongs to meta-training, which is often called teaching the mind to learn, referring to "internal processes, how we comprehend and adapt to learning" (Fadle, Bialik, Trilling: 91). In other words, the reform in education is caused by teaching schoolchildren to strive for improvement regardless of the goals set. Such an approach contributes to the formation of the students' internal attitude such as "I learn how to act," rather than the principle "I learn about the subject" (Interv'iu s A.Zh. Kultumanovoi, 2014: 13).

It is important to note that a significant factor in the implementation of the education reform is training of $10^{\text {th }}-11^{\text {th }}$ graders within a trilingual program starting from the school year of 20192020, when the subjects "Biology", "Chemistry", "Informatics" will be taught in English, while "Kazakh language and literature", "Kazakh history" in schools with the Russian language of study will be taught in the Kazakh language, the subjects "Russian language and literature" in schools with the non-Russian language of study will be taught in Russian. By that time, 16.5 thousand teachers are to be trained for teaching in English. At the moment, 1500 teachers across the country have started teaching in English as part of a "big experiment".

In terms of the level of proficiency in English, Kazakhstan in the rating of the English Proficiency Index is as follows (Table 1).

The reasonableness and timeliness of the education reform is explained, on the one hand, by the above facts illustrating the state of school education in Kazakhstan. On the other hand, the maturing within the traditional system of 
Table 1. Conceptual bases of research

\begin{tabular}{ll}
\hline $\mathbf{2 0 1 1}$ & $44^{\text {th }}$ place among 44 countries \\
\hline $\mathbf{2 0 1 3}$ & $57^{\text {th }}$ place among 60 countries \\
$\mathbf{2 0 1 4}$ & $54^{\text {th }}$ place among 63 countries \\
$\mathbf{2 0 1 5}$ & $54^{\text {th }}$ place among 70 countries \\
$\mathbf{2 0 1 6}$ & $54^{\text {th }}$ place among 72 countries \\
$\mathbf{2 0 1 7}$ & $67^{\text {th }}$ place among 80 countries \\
\hline
\end{tabular}

learning, the recognition of the advantages of the communicative-activity approach, the use of interactive teaching methods (ITM) by teachers-innovators, the creation of experimental schools have prepared the evolution of scientific ideas about modern didactics and its role for social adaptation of the school leaver to the requirements of the time, opportunities to realize oneself. A new understanding of the effectiveness of teaching in didactics has become a cornerstone of the reform in the system of school education.

For modern didactics, the experience of developing an innovative standard of literature education in the Russian Federation turned out to be fruitful, reflecting the influence of literary criticism on the development of methodology and textbooks by N.D. Tamarchenko for schools with an in-depth study of humanitarian subjects (Tamarchenko, 1995), I. Sukhikh (Sukhikh, 2011), G.V. Moskvin and others (Moskvin et al., 2012). We should note the role of the methodology of communicative didactics and the work of V.I. Tiupa (Tiupa, 2011) for the Kazakh school system of secondary education. In the conditions of methodological pluralism in literary criticism and methods of teaching literature, the struggle of alternative didactic strategies, "the strategy of revelation" and "the learning strategy", Tiupa substantiated the role of three paradigms of literary knowledge, namely, the history of literature, poetics, aesthetic discourse. Tiupa and Troitskii write about the priority of consent over the discussion (Tiupa, Troitskii, 2004).
This approach became the basis for the development of a text-centric approach as the base for learning, and not only for building skills for qualified, competent reading, but also for solving the tasks of language learning.

The understanding of the effectiveness of teaching, caused by the practical tasks of teaching the subject in didactics, has also changed. Within the traditional approach, the effectiveness of teaching meant the effectiveness of mastering the topic discussed in the lesson. Today the researchers see the strategic role of the modern understanding of learning "in the formation of students' skills to work not at the level of actions and operations (when the goal is set and not subject to discussion), but at the level of activity (when the goal is covered by the meaning and the person has the opportunity to choose the methods of activity)" (Pisaruk, 2008: 70).

The urgency of the communicative-activity approach is due to a number of circumstances. The concept of communication lies at the basis of almost all modern approaches to culture and education of the individual in school and university. From the standpoint of linguistics, communicative culture is identified with the concept of "good speech" (A.G. Baranov, G.I. Bogin, Iu.N. Karaulov, O.B. Sirotinina, etc.); psycholinguistics understands a culture of speech activity as the communicative culture (G.A. Galperin, N.I. Zhinkin, A.A. Leontiev, etc.); lingvopragmatics sees an effective influence on the interlocutor as the communicative culture (S.V. Znamenskaia, O.M. Kazartseva, V.V. Safonova, etc.). The desire to establish a correspondence between the communicative culture and the effective interaction of subjects is common to these definitions.

How does the communicativeactivity approach concretize the concept of communicative competence and how does it affect the content, for example, of the subject 
"Russian Language and Literature" in a school with a non-Russian language of study? According to L.A. Murina, there are two positions: 1) "The three components that make up communicative competence, namely, the functional aspect of the language system, the quality of the speech culture, and the types of speech activity, should be the main content of language learning in the school"; and 2) "to develop the communicative competence of schoolchildren, a purposeful methodological system that implements anthropocentric and textocentric approaches to language learning is necessary" (Pisaruk, 2008: 11).

The question of the effectiveness of teaching the subject "Russian language" (in the context of the problem discussed in this article) arose on the basis of a critical assessment that revealed the inadequacy of teaching norms and rules of the language, as well as the importance of teaching productive speech actions. As I. Miloslavskii writes, "What kind of effectiveness can be discussed here, if the speaker/writer simply does not have the appropriate stock of words, phraseological units, syntactic constructions, or has a vague idea of the reality behind the language units that exist for him only phonetically or only in the form of spelling?" (Miloslavskii, 2011, Online).

It is known that traditionally the method of teaching languages was focused on the achievements of linguistics, i.e. on the study of the system of language, the aggregate of linguistic units and regularities. However, this approach contributed to the formation of the skills of one type of speech activity, namely, writing, while a necessary condition for communication and the formation of a communicative personality is a compulsory acquisition of all types of speech activity - reading, speaking, writing, listening. Hence there is a shift of the learning focus onto learning speech activity, with the support of the textocentric approach as opposed to the linguocentric one.

An important seed of the communicative and activity approach is the formation of students' motivation to search for information. It is known that scientists distinguish between inquisitiveness as a "desire to know" and curiosity as a "state". Thus, American researchers write, "The theory of interest/deprivation unites concepts from various models of curiosity and neuropsychology, desires and rewards, arguing that curiosity includes both the emergence of a positive sense of interest, and the removal of a negative sense of uncertainty" (Fadle, Byalik, Trilling: 169).

Hence there is the ambiguous and contradictory attitude to the devices as one of the most popular source demanded by the modern training practice. On the one hand, there is the awareness of the need to be able to work with electronic resources, develop skills in selecting the right information, filtering the main and secondary information, on the other hand, there is parents' fear of creating dependence of students on the Internet and a passing acquaintance with the dubious resources that are dangerous for the mind of adolescents. Here the experience of Moscow teachers in the field of forming a culture of working with electronic sources and forming computer literacy is interesting. Encouraging teachers and students to use gadgets in particular as a source of text, the authors consider two circumstances. Firstly, the results of sociological studies in Russia, show that $83 \%$ of respondents use smartphones to communicate in social networks and through messengers. For $67 \%$, the main thing in a smartphone is games and entertainment applications. Only $50 \%$ and $33 \%$ of the survey's participants use gadgets for work and study (Korobatov, 2017). Secondly, the principle of testing is the basis of "educational" applications for smartphones and tablets, when the inclusion 
of the student's visual memory ensures that the correct answers are stored. Therefore, not from the point of view of didactics, but from the point of view of searching for texts for study, the appeal to electronic resources is justified, being a part of the learning strategy.

The appeal to electronic resources seems to be effective in terms of developing a system-thought-based approach developed by G.P. Shchedrovitskii. Hence there is the demand in Russia for teams that are capable of creating advanced solutions. These are federal "nonsystem" projects, such as "Talent's Deposit", "Sirius", "Innopractice", "Quantoriums", "Lift to the Future", TSMITs. The goals of the training in the updated program in Kazakhstan are also aimed at the forecasting and creation of advanced solutions.

\section{Problem statement}

Why is reform necessary in education and, in particular, in teaching Russian as a non-native language and Russian literature? How does the model of the communicative-activity approach ensure the effectiveness of the education reform? What should be understood as the effectiveness of introducing a new standard of education and a long-term program developed by NIS (Nazarbayev Intellectual Schools) for general education schools in the Republic of Kazakhstan, and what should the textbook with updated content on the subject "Russian Language and Literature" be for general schools with a nonRussian language of study?

This article aims to highlight these issues and illustrate the main provisions of the communicative-activity approach on the basis of the teaching materials for the subject "Russian Language and Literature" for the $6^{\text {th }}$ grade of comprehensive schools with a non-Russian language of study (8), which is being tested and developed for the 2017-2018 school year.
The considered educational-methodological concept embodies the ways of the formation of literacy from the viewpoint of the formation of the skills to create texts that provide communication, publicly perform, adapt to different speech situations, detecting the generated speech behavior, clearly, precisely state and rationalize a point of view, understand and analyze other people's speech, read and accurately interpret texts and much more.

Among the three models of teaching Russian in Kazakhstan, namely, teaching Russian as a native language, a non-native language or a foreign language, the concept of learning Russian as a second language in secondary schools with a non-Russian language of study is based on the previous experience of the authors in completing teaching materials, which included a textbook, a reader and a teacher's guide to implement the integration of subjects "Russian language" and "Russian Literature" in the aspect of development of speech activity since 2015 .

\section{Methods}

When writing the article, the authors applied philological, hermeneutic, comparative-historical methods.

\section{Discussion}

A comparative analysis of the mentioned teaching materials with earlier 13 editions of the textbook "Literary reading" written by the same authors (Nurtazina, Suleimenova, Urazaeva, 2015a) allows showing the advantages of implementing the technology of a communicative-activity approach, its continuity with the conventional method. The book and the teaching materials on its basis ("Reader" and "Teaching guide for the teacher") have existed since 1954. Even in the 70-80ies within the framework of teaching speech activity the researches anticipated concepts and 
categories that make up the pedagogical tools and are still relevant: Innovative technologies, bilingualism and multilinguism, activation of cognitive activity, interactive teaching methods, problem-based learning, etc. The author of many editions of the book was Rafika Bekenovna Nurtazina, Hero of Socialist Labor, laureate of A. Pushkin's awards, "Tarlan", veteran and classic of the Kazakhstan school system, who stood at the foundations of linguodidactics in the republic. At school No. 12 in Almaty, organized as a boarding school, the active methods of teaching the Russian language and literature were tested to get the country's recognition. More than one generation of Soviet schoolchildren grew up on the "Entertaining Grammar" of R.B. Nurtazina, which has withstood more than one edition.

Since 2015, the integration of the subjects "Russian Language" and "Russian Literature" has confirmed, on the one hand, the priority of textocentric learning in teaching Russian as a nonnative language, on the other hand, has highlighted the importance of shifting the educational paradigm from a knowledge-centered approach to the formation of skills and competences. The concept of the teaching materials of 2015 is based on the model of the competency-based approach, in which the selection and placement of material, as well as tasks that take students outside the boundaries of understanding a specific artistic text, represented the assistance to learners in the process of social adaptation. The continuation of the strategy of "learning with a smile" was aimed at developing logical thinking, memory and imagination, working out the purity of pronouncing sounds, understanding differences in the native and Russian phonetics, solving problems of the social and personal development of students. The introduction of such works in reading as "Golden Words" by M. Zoshchenko, "At the Back Desk", "Nobody and Others", "Who
Looks Like Someone Else", "My Imagination", "The Shaggy ABC" by B. Zakhoder, "Harmful Advice to rogues and thieves" by G. Oster and others contributed to the activation of students' observation, logical thinking, imagination, visualization of hidden images. The study of the imaginative nature of riddles, fairy tales, fables, parables is justified from the standpoint of the development of cognitive, creative thinking and memory. Offering the models of ready-made answers in the textbook, the authors solved the problem of controlling the correctness of judgments and developing a self-monitoring mechanism for schoolchildren.

Tasks of textbooks always included ways of teaching the skills of composing funny stories. The authors attached great importance to the development of speech culture by selecting synonyms, understanding the meaning and correct use of phraseological phrases, paid attention to examples of semanthization, which expanded the lexical fund of students studying in a non-native language, understanding and applying rules for constructing speech. Education through careful attitude to the language, careful attitude to culture and man was considered as the main task of education. The inclusion of educational tasks in the content of the game ensured the students' motivation for studying the Russian language and literature. The experience of the game form of interaction between the teacher and students was developed through the realization of a certain plot (a game, a fairy tale, a performance, business communication).

With the traditional approach, the study of the rules and norms of the Russian language ensured the formation of skills of only one type of speech activity, namely writing, while now the learning of speech activity presupposes a comprehensive approach, the coverage of four types of speech activity - reading, speaking, writing, listening as a necessary condition for communication and 
the formation of a communicative personality. The specificity of teaching the Russian language as a non-native language is conditioned by the orientation of the program for teaching units of language communication to schoolchildren.

The Russian Language and Literature textbook with updated content for a general school with a non-Russian language of study (Nurtazina, Suleimenova, Urazaeva, 2017b) contains sections "The nature and appearance of a person", "The world around us", "Ancient and modern civilizations", "Astronomy. Planets and stars." This structuring corresponds to the principle of creating textbooks on the Russian language and literature in the focus of comparative linguocultural studies, which provide for the formation of motivational preferences of students. The implementation of the principle of the costudy of language and culture is the basis for the development of the teaching materials.

Modern society needs a person who has the skills of free speaking, literate and free writing, adequately understanding the meaning of a "read" or "heard" text (an "alien" text), as well as the main content of one's own text and the means of delivering it to the addressee. The practical importance of such skills is due to the achievement of mutual understanding in communication. Hence there is such a trend in school and university education as rhetorization. The reform in teaching Russian as a non-native language is based on the understanding of the communicative personality as a person in their ability and readiness for communication. A practical goal that is the formation of communication skills appears to replace the former teaching. The textocentric approach to teaching speech and literature, which is the main condition for the formation of the student's linguistic personality, is determined by the practical nature of teaching the language as a non-native one and Russian literature.
The new nature of goal-setting led to the structuring of the lesson and the formulation of measurable (achievable) results that determine the differentiation of types of learning activity and differentiated results. The individualdifferentiated approach is based on the principles of complexity of tasks, the organization of different types of speech activity, the organization of learning activities in different-level groups.

In the textbook for the $6^{\text {th }}$ grade in accordance with the program, the authors offer the following situational (communicative) tasks: write congratulations, an explanatory note, a receipt, create advertising. In this case, in particular, the strategy of "studying with a smile" (for example, compose, with the requirements for content and structure, a receipt on behalf of the Fox on obtaining cheese from the Crow based on the example of the fable of I.A. Krylov, or write an explanatory letter to a doctor about the violation of a diet within studying the topic "Healthy lifestyle") is tested. The means of achieving the goal is the practical use of language, for which it is necessary to create conditions for verbal communication. As I. Miloslavskii emphasizes, "The ability to model possible events and their consequences is a very necessary aspect of improving the intellect" (Miloslavskii, 2011). Thus, students of the $6^{\text {th }}$ grade are encouraged to simulate such situations, for example, when studying of A.P. Chekhov's "Chameleon", or fulfilling the task "Turn on the imagination": imagine that Khriukin, poking a dog with a cigar in the nose, and bitten by it, beat the dog, and Ochumelov forced Khriukin to write an explanatory letter. Look at the sample of the explanatory note and write it on behalf of Khriukin. Use colloquial vocabulary and quotes. What are the longterm consequences of such techniques? Let us give an example from Russian reality. Thus, working with the humanitarian methodology 
allowed its author to identify Nazi youth groups and then "switch" them from the style of life of the "natsiki" to military-patriotic communities (Sergeev, 2017). This is due to a "special" discussion of history with the youth and the transmission of a "special understanding" of the contemporary socio-political situation. This fact illustrates the shift of the learning focus from the subject content to the meta-subject result. It is no coincidence that the sections in the program are called somewhat unexpectedly, "The World Around Us", "Ancient and Modern Civilizations", "Astronomy. Planets and stars", which does not mean studying biology, history, astronomy in the lessons of the Russian language and literature.

The expansion of the student's vocabulary due to work on understanding and use of phraseological phrases, paronyms, borrowed words, etc. allows providing motivation of schoolchildren as an important element of the organization of educational activity, determines both the need for communication and the desire for it. It is now recognized that the transition from discipline to self-determination of students and from explanations to understanding (Asmolov) should be the distinctive feature of the new school (Lokomotivom rossiiskogo obrazovaniia..., 2017). Besides, when performing assignments in a school with a non-Russian language of study, the work of students connected with listening to a text is very important.

With the new approach, the system of teacher-student relations is changing. The form S-S, subject-subject activity, means the replacement of the authoritarian and dominant word of the teacher, shifting the emphasis on the priority of the creative activity of the student. If the study of the rules and norms of the Russian language ensured the formation of writing skills, then the essence of teaching speech activity now is the desire for comprehensive mastery of all types of speech activity, namely reading, speaking, writing, listening, as a necessary condition for communication and the formation of a communicative personality. The specificity of teaching Russian as non-native language is conditioned by the orientation of the program for teaching units of language communication to schoolchildren.

The goal setting is realized in giving the motivation for action to the names of tasks, such as "Write to the blog", "Write a story", "Discuss the picture". The methods of pedagogy of cooperation are used, namely "Let's do it together". The national component in "Overplay Aldar", "Become Zhirenshe" is also used. With the help of tasks "For and against", "Truth is born in a dispute", "Brainstorming", etc., critical thinking is realized.

The concept of developmental learning manifests itself in a program format that the teacher is unfamiliar with, when within a term it is recommended to study 2-3 small texts on average. It can be novels or poems. The accompanying texts, assignments, illustrations are selected taking into account the implementation of intersubject communications and text-centric learning.

The peculiarity of the implementation of the modern approach is the individual-differentiated approach, in which the degree of complexity of tasks differs, different types of speech activity are combined $\left(\mathrm{L}^{1}+\mathrm{S}+\mathrm{R}, \mathrm{L}+\mathrm{S}+\mathrm{W}\right)$, the principle of organizing educational activity in differentlevel groups is observed. Let us note that now the role of the concept of "high-hum" (high-hum means humanitarian technologies) is increasingly asserted as "a set of knowledge, spiritual and cultural values, as well as methods of information transfer that organize people and encourage them to a certain collective activity" (Sergeev, 2017). The authors recommend combining such types of learning activities in the classroom as individual, 
pair, group, collective to create a collaborative and safe environment for students, where they hone their teamwork skills.

Differentiation is also carried out according to the prevailing type of perception of information that is either an auditory or a visual channel, and propensity to a kinesthetic type. The need to develop different channels of information perception explains the inclusion of audio recordings, reproductions of classical painting and works by contemporary artists of Kazakhstan, such as I. Iarema, M. Vedernikov, etc. It is important to note the new, independent methodological role of the illustration in the lesson of teaching Russian as a non-native language. These are the following functions: to show; to explain; to check understanding; to demonstrate the process; to start thinking; to open a discussion; to stimulate writing; to present the context. Differentiation of activities and differentiated results ensure the attainability of learning objectives through the measurability of results.

In the new approach, a new role for evaluation is stated. What is behind the term "quality loop" and the chain of concepts that lie behind it: teaching - learning - assessment - improving teaching? How is evaluation related to problem solving, not the achievement of results? This is an understanding of the role of evaluation as an element of learning and a motivation factor of the student, who correlates with the concept of a leader. Whom did we consider the leader before and whom now?

The authors of the book "Four-dimensional education" identified the type of students, who face the goal of achieving academic progress (associated with a fixed affirmation). "They are more concerned by the fact that the people around us understand that they have mastered the material taught. Students oriented to learning are inclined to perceive mistakes as opportunities for growth and development, while those oriented toward academic progress perceive them as failures. As a result, learner-centered students spend more effort when faced with problems, whereas those oriented toward academic progress spend less effort," the researchers note (Fadle, Bialik, Trilling: 187). In other words, the student's recognition of one's own developmental potentials, the focus on development for confidence and the ability to develop successfully helps them to realize their personal significance and own capabilities; forms the understanding that ignorance at this stage does not determine the assessment, that evaluation is not a fixation of results, but a point, which is followed by a new round of development, improvement in the quality of education and the level of education.

The perception of a person that influences the result, the decision made in the group as a leader, can determine the regrouping of pupils traditionally considered successful and so-called strong "averages". A person learns to overcome shyness, indecision, possessing specific knowledge, becomes able to influence the performance of a collective task. Thus, unconsciously, and then consciously the person is motivated to develop in learning, realizing its role for success. The introduction of the concepts of formative and cumulative assessment into the practice of schools correlates with the beliefs of Russian experts on the need to reject assessments (Voloshin, 2017). To evaluate not only training but evaluate for training is the principle of evaluation as an element of training.

The development of information literacy explains one of the main arguments of the public against textbooks that have been subjected to obstruction. In those textbooks the experts noticed a replacement of real learning by the independent work of students with the involvement of the Internet, fears of involving adolescents in banned social networks. Here we 
can cite the authoritative opinion of the Moscow educator, "There is an opinion that since there is the Internet now, children do not need to be pumped up with information, they need to learn only competencies. First of all, competencies as well as skills and abilities do not exist without knowledge, and all this can be formed only in unity, and not opposed to one another" (Katsva, 2017).

How are the implementation of the national component and the formation of social skills implemented in the new textbook? The notion of "high-hum" as "a set of knowledge, spiritual and cultural values, as well as methods of information transfer, organizing people and encouraging them to a certain collective activity" (Sergeev, 2017) defines modeling different types of learning activities in the lesson, such as individual, pair, group, team work to create a collaborative and safe environment for students.

\section{Conclusion}

Thus, the predicted result of the implementation of the communicative-activity approach in training is characterized by the following knowledge and skills:

- fluency in Russian literary language;

- steady interest in reading;

- stimulation of independent productive educational and creative activity;

- growth of cognitive activity;

- development of critical thinking;

- formation of skills of literary analysis and interpretation of a literary text;

- development of skills of self-evaluation and mutual evaluation.

Letters denote types of speech activity: $\mathrm{L}$ - listening, $\mathrm{R}$ - reading, $\mathrm{S}$ - speaking, $\mathrm{W}$ - writing.

\section{References}

Boranbaeva, Z.I. (2017a). Chto ne tak s novymi uchebnikami po russkoi literature dlia kazakhskikh shkol? [What is wrong with the new textbooks on Russian literature for Kazakh schools?]. Available at: www: informburo.kz/stati/chto-ne-tak-s-novymi-uchebnikami-po-russkomu-yazyku-dlya-kazahskihshkol.html

Boranbaeva, Z.I. (2017b). Chto ne tak v uchebnikakh russkoi literatury dlia kazakhskikh shkol? [What is wrong in the textbooks on Russian literature for Kazakh schools?]. Available at: www. total. kz/ru/news/obshchestvo_sobitiya/chto_ne_tak_v_uchebnikah_russkoi_literaturi_dlya_kazahskih_ shkol_date_2017_10

Fadle Ch., Bialik M., Trilling B. Chetyrekhmernoe obrazovanie [Four-dimensional education]. Available at: www.skolkovo.ru/public/images/stories/news/2016/SKOLKOVO_SEDeC_4D_ Education.pdf

Igisinova, A. (2017). Okolo 20 tysiach kazakhstanskikh vypusknikov v etom godu uedut uchit'sia za rubezh-ekspert [About 20 thousand Kazakhstan graduates will leave to study abroad this year: an expert]. Available at: www" informburo.kz/novosti/okolo-20-tysyach-kazahstanskih-vypusknikov-vetom-godu-uedut-uchitsya-za-rubezh-ekspert.html). Date: August 23, 2017, 00:23.

Interv'iu s A.Zh. Kultumanovoi, direktorom Natsional'nogo tsentra obrazovatel'noi statistiki i otsenki [Interview with A.Zh. Kultumanova, Director of the National Center for Educational Statistics and Evaluation] (2014). In Chelovecheskii kapital, [Human Capital], 1. Available at: www: nac.nu.edu. kz/images/Billuten/pdf/Kapital/CH_11_may2014.pdf/, p. 13.

Kazakhstan zanial 59 mesto iz 65 stran po otsenke gramotnosti shkol'nikov [Kazakhstan ranked $59^{\text {th }}$ out of 65 countries in the literacy assessment of schoolchildren] (2015). Available at: 
www.kt.kz/rus/education/kazahstan_zanjal_59_mesto_iz_65_stran_po_ocenke_gramotnosti_ shkoljnikov_1153529071.html

Katsva, L. (2017). Ia by ne gordilsia uspekhami moskovskogo obrazovaniia [I would not be proud of the successes of Moscow education]. Available at: www.pravmir.ru/ya-by-ne-gordilsa/. Accessed October 5, 2017

Korobatov, Ia. (2017). Issledovanie: chem vyshe uroven' obrazovaniia, tem men'she zavi-sish' ot smartfona. Uchenye vyiasnili, dlia chego moskvichi ispol'zuiut mobil'niki (opros “KP”) [Research: the higher the level of education, the less you depend on a smartphone. Scientists found out why people in Moscow use mobile phones (a survey)]. Available at: https://www.kp.ru/daily/26749/3778530/

Lokomotivom rossiiskogo obrazovaniia stali kolledzhi [Colleges became the engine of Russian education]. Available at: www.mk.ru/social/2017/11/12/lokomotivom-rossiyskogo-obrazovaniya-stalikolledzhi.html.

Miloslavskii, I.G. (2011). Pravila vmesto smysla [Rules instead of meanings], In Znamia [Flag], 12. Available at: www: magazines.russ.ru/znamia/2011/12/mi14.html.

Moskvin, G.V., Puriaeva, N.N., Erokhina, E.L. Literatura. 5 klass: uchebnik dlia uchashchikhsia obshcheobrazovatel'nykh uchrezhdenii: v 2 ch. Chast' 2 [Literature. Grade 5: textbook for students of general education institutions: in 2 parts. Part 2]. Moscow, Ventana-Graf, 256 p.

Nurtazina, R.B, Suleimenova, E.D., Urazaeva, K.B. (2015a). Literaturnoe chtenie. Uchebnik, 13-e izdanie [Literature reading. Textbook. $13^{\text {th }}$ edition]. Almaty, Bilim, $176 \mathrm{p}$.

Nurtazina, R.B., Sulejmenova, E.D., Urazaeva, K.B. (2015b). Russkii iazyk i literatura dlia 6 klassa obshcheobrazovatel'nykh shkol s nerusskim iazykom obucheniia. UMK [Russian Language and Literature for the $6^{\text {th }}$ grade of general education schools with a non-Russian language of study. Teaching materials]. Almaty, Bilim, Uchebnik v 2 chastiak [Textbook in 2 parts] (134 p., 172 p.), "Rabochaia tetrad" $\mathrm{v} 2$ chastiakh [Workbook in 2 parts] (98 p., 160 p.), "Kniga dlia uchitelia" [Teacher's Book], 82 p.

Pisaruk, G.V. (2008). Metodika prepodavaniia russkogo iazyka v voprosakh i otvetakh. Metodika prepodavaniia russkogo iazyka v voprosakh i otvetakh: spravochnoe posobie [Methodology of teaching Russian language in questions and answers: reference book]. Brest, Akademiia, 101 p.

Progress funktsional'noi gramotnosti shkol'nikov v Kazakhstane (2014). In Chelovecheskii kapital [Human Capital], 1. Available at: http://nac.nu.edu.kz/images/Billuten/pdf/Kapital/CH_11_may2014. pdf., 10-11.

Sait Respublikanskogo nauchno-prakticheskogo tsentra «Uchebnik» MON RK [Site of the Republican Scientific and Practical Center "Uchebnik" of the Ministry of Education and Science of the Republic of Kazakhstan]. Available at: www: expert.okulyk-edu.kz/

Satpaev, D. (2017). Dolzhna byt' konkurentsiia mozgov, a ne pontov [There must be competition of brains, not richness]. Available at: www: ratel.kz/outlook/dolzhna_byt_konkurentsija_mozgov_a_ ne_pontov/, October 31, 2017, 09:00.

Sergeev, I.U. (2017). Obrazovanie - eto obraz budushchego. Interv'iu s ekspertom [Education is the image of the future. Interview with an expert]. Available at: https://eadaily.com/ru/news/2017/09/30/ obrazovanie-eto-obraz-budushchego-intervyu-s-ekspertom. Accessed 30 September 2017.

Sukhikh, I.N. (2011). Literatura. 11 klass. Uchebnik v 2 chastiakh (bazovyi uroven') [Literature. $11^{\text {th }}$ grade. Textbook in 2 parts (basic level)], 4. Moscow, Academiia, Part 1, 352 p., Part 2, 368 p. 
Tamarchenko, N.D. (1995). Puteshestvie v «chuzhuiu» stranu. Literatura puteshestvii $i$ prikliuchenii. Uchebnoe posobie po literature dlia $5 \mathrm{kl}$. shk. gumanit. tipa [Travel to a "foreign" country. Literature of travel and adventure. Literature textbook for the $5^{\text {th }}$ grade of a humanitarian school]. Moscow, Aspekt-Press, 239 p.

Tiupa, V.I. (2011). Innovatsionnyi standart literaturnogo obrazovaniia [Innovative standard of literary education]. Available at: www: metlit.nm.ru/materials/communic/innovst.html.

Tiupa, V.I., Troitskii, Iu.L. (2004). Osnovy kommunikativnoi didaktiki [Fundamentals of communicative didactics], In Kommunikativnaia pedagogika: ot «shkoly znaniia» $k$ «shkole ponimaniia». Materialy nauchno-prakticheskoi konferentsii [Communicative pedagogy: from "the school of knowledge" to "the school of understanding". Proceedings of Research-to-Practice Conference]. Novosibirsk, 43-51.

Voloshin, D. (2017). Ot otsenok v shkole pora otkazyvat'sya [It's time to abandon school marks]. Available at: www: newizv.ru/article/general/04-05-2017/dmitriy-voloshin-ot-otsenok-v-shkole-poraotkazyvatsya

Zagribel'nyi, A. (2017a). Shutingom - po mundialiu [Shooting the Mundial]. Available at: www. time.kz/articles/ugol/2017/10/02/sutingom-po-mundialju. October 2, 2017, 9:30

Zagribel'nyi, A. (2017b). Uchit' nel'zia pomilovat'! [Teach cannot pardon!]. Available at: www: i-news.kz/news/2017/10/03/8628911-aleksandr_zagribelnyi_uchit_nelzya_pomil.html, date: October 3, 2017, 10:59.

\title{
Школьные учебники с обновленным содержанием в Казахстане в аспекте реформы в образовании
}

\author{
Э.Д. Сулейменова ${ }^{a}$, Г.Е. Кожамкулова ${ }^{\sigma}$, \\ К.Б. Уразаева ${ }^{\mathrm{B}}$ \\ ${ }^{a}$ Казахский начиональный университет им. аль-Фараби \\ Казахстан, 050040, Алматы, пр. аль-Фараби, 71 \\ ${ }^{\sigma} Ц$ Центр образовательных программ \\ AOO «Назарбаев Интеллектуальные школыр» \\ Казахстан, 010000, Астана, ул. 31/35 \\ ${ }^{6}$ Евразийский национальный университет \\ Казахстан, 010008, Астана, ул. Сатпаева, 2
}

Реализация реформы в системе школьного образования Республики Казахстан, обусловленная необходимостью создания конкурентоспособного образования на фоне усиления образовательной миграции (оттока выпускников школ) и важности разработки политики «обратной» миграчии, привела к разработке новых стандартов, типовых программ и учебников с обновленным содержанием.

Переход на трехъязычие, в частности, преподавание биологии, химии и информатики в 10-11-х классах на английском языке с 2019 г. является частью внедрения модели, апробированной в Назарбаев Интеллектуальных школах, продемонстрировавших высокие результаты по PISA, в общеобразовательной школе. 
В статье описаны факторы реформы в образовании и опыт разработки учебно-методического комплекса по предмету «Русский язык и литература» для 6 класса общеобразовательной школы с нерусским языком обучения. Современное понимание результативности обучения, преимуществ коммуникативно-деятельностного подхода иллюстрируется примерами нового целеполагания, дифференциачии и прогрессии, организации и комбинации видов учебной деятельности, нового подхода к очениванию как элементу обучения, применения межпредметного подхода.

Методологическая база статьи характеризуется применением современных концепщий, касающихся достижений дидактики, риторики, лингвокультурологии.

Полученные авторами результаты могут быть использованы в области дидактики средней и высшей школы с точки зрения активных методов обучения, комплексного обучения речевой деятельности, методики обучения речеведческим дисчиплинам в национальной аудитории.

Авторами описан опыт по выработке навыков свободного говорения, аргументированного письма, интерпретации «чужого» текста, а также обоснована практическая значимость названных умений для успешной сочиальной интеграции учащиххя.

Ключевые слова: русский язык и литература, Казахстан, средняя школа, реформа в образовании, коммуникативно-деятельностный подход, обновленное содержание.

Научная специальность: 13.00.00 - педагогические науки. 